\title{
NIPPON KAIGI: \\ GERAKAN KEBANGKITAN NASIONALISME JEPUN
}

\author{
Asmadi Hassan dan Abdul Rasyid Mokhtar
}

\begin{abstract}
Abstrak
Nippon Kaigi merupakan kumpulan pendesak berhaluan kanan yang berpengaruh di Jepun. Keahliannya bukan sahaja dalam kalangan orang biasa, tetapi juga ahli politik berpengaruh, golongan profesional, peniaga, kumpulan agama, presiden universiti, ahli akademik dan ketua hakim. Matlamat mereka adalah untuk membina sebuah negara Jepun yang penduduknya berbangga menjadi rakyatnya (nasionalisme). Artikel ini membincangkan gerakan untuk membangkitkan nasionalisme oleh Nippon Kaigi di Jepun dan bagaimana mereka mencapai matlamat yang disasarkan. Ia dibahagikan kepada tiga bahagian iaitu pengenalan tentang Nippon Kaigi, kesongsangan Jepun sekarang sehingga menimbulkan keperluan membangkitkan semangat nasionalisme dan gerakan membangkitkan semangat tersebut. Kajian ini mendapati bahawa pergerakan pertubuhan ini tidak melalui keganasan dan kekerasan seperti yang dilakukan oleh pertubuhan haluan kanan di negara-negara lain tetapi melalui aktiviti propaganda politik. Untuk menyebarkan ideologi dalam kalangan orang ramai, ia meletakkan keutamaan tertinggi dalam perhimpunan besar, mengumpul tandatangan dan meluluskan resolusi dewan tempatan di seluruh negara. Dalam erti kata itu, Nippon Kaigi menggunakan pendekatan baharu untuk pergerakan sivil berhaluan kanan.
\end{abstract}

Nippon Kaigi is an influential right-wing pressure group in Japan. Its membership is not only among the ordinary people, but also influential politicians, professionals, businessmen, religious groups, academics and chief justices. Their goal is to build a nation whose people are proud to be citizens (nationalism). The article discusses the movement by Nippon Kaigi to nurture nationalism in Japan and how it achieved its goals. The article is divided into several parts, namely the introduction of Nippon Kaigi, the oddity of current Japanese society which led to the need for a spirit of nationalism and the movement in Japan. The study found that the activities of this organization is not through violence but by political propaganda activities. In order to disseminate its ideology among the citizens, it holds assemblies, collecting signatures and calls for local assembly approval across the country. In other words, Nippon Kaigi has employed a new approach to advance right-wing movements.

Keywords: Nippon Kaigi, nationalism, Japanese right wing movements, political propoganda 


\section{PENGENALAN}

Setiap orang mempunyai kepentingan, keutamaan dan masalah sendiri yang memerlukan penyelesaian di peringkat politik. Mereka berkongsi masalah dan kepentingan dengan bergabung dalam sesuatu organisasi untuk menyuarakan kepada pemerintah. Tindakan secara kolektif membolehkan desakan diambil kira secara serius oleh pemerintah. Contoh kumpulan tersebut adalah seperti persatuan pelajar, pertubuhan profesional, kesatuan sekerja, pertubuhan alam sekitar dan persatuan pengguna. ${ }^{1}$ Menyertai kumpulan tersebut membolehkan mereka menjalankan desakan ke atas pihak berkuasa secara aktif bagi menjayakan matlamat yang disasarkan. Menurut Maurice Duvenger, perbezaan parti politik dengan kumpulan pendesak adalah parti politik wujud untuk mendapatkan dan menggunakan kuasa. Manakala kumpulan pendesak bertindak untuk mempengaruhi kuasa yang diperolehi oleh parti politik terutamanya dalam pembentukan dasar awam. Kumpulan ini berusaha ke arah mempengaruhi dasar tertentu bagi mendapatkan dan mempertahankan kepentingan mereka. ${ }^{2}$ Di Jepun terdapat banyak kumpulan pendesak yang mempengaruhi kerajaan melalui kekuatan yang dimiliki, sama ada melalui kuasa mengundi dalam pilihan raya, sumber kewangan, hubungan rapat dengan pemimpin kerajaan dan sebagainya. Sekiranya tuntutan tidak dituruti akan memungkinkan penarikan balik sokongan yang selama ini diberikan. ${ }^{3}$ Contoh kumpulan pendesak yang terkenal di Jepun adalah Japan Association of Bereaved Family (Nippon Izokukai), Japan Conference (Nippon Kaigi), Military Pension Federation (Gunjin Onkyu Renmei: MPF), Association of Shinto Shrine (Jinja Honcho). Kumpulan pendesak ini berhaluan kanan yang menetapkan matlamat untuk menjadikan Jepun sebagai sebuah negara yang dihormati dan mempertahankan negara dari kritikan dari dalam dan luar negara terutamnya dalam isu wanita pelayan kepada tentera Jepun, buruh paksa semasa Perang Pasifik dan lawatan pegawai kerajaan ke Kuil Yasukuni. ${ }^{4}$

Artikel ini membincangkan gerakan untuk membangkitkan nasionalisme oleh Nippon Kaigi dan bagaimana mereka mencapai matlamat yang disasarkan. Ia dibahagikan kepada tiga bahagian iaitu pengenalan tentang Nippon Kaigi, kesongsangan Jepun sekarang sehingga timbul keperluan membangkitkan semangat nasionalisme dan gerakan membangkitkan nasionalisme di Jepun.

\section{NIPPON KAIGI}

Nippon Kaigi ditubuhkan pada 30 Mei 1997 dengan menggabungkan dua pertubuhan berhaluan kanan, Nihon Wo Mamoru Kokumin Kaigi (The National Conference to Defend Japan) dan Nihon Wo Mamoru Kai (Society for the Protection of Japan). ${ }^{5}$ Walaupun Nippon Kaigi ditubuhkan pada tahun $1997,{ }^{6}$ tetapi pertubuhan ini mula terkenal pada tahun 2015 apabila beberapa buku dan majalah yang memfokuskan kepada pertubuhan ini mendapat perhatian ramai sehingga

\footnotetext{
${ }^{1}$ Ahmad Shukri Mohd Nain, Rosman Md. Yusoff, Konsep, Teori, Dimensi \& Isu Pembangunan. Universiti Teknologi Malaysia Press, 2003. hlm. 170-171.

${ }^{2}$ Syed Ahmad Hussein, Pengantar Sains Politik, Kuala Lumpur: Dewan Bahasa dan Pustaka, 2006, hlm 235.

3 Taguchi, F, "Pressure Groups in Japanese Politics", The Developing Economies, 6(4), 1968, hlm. 476.

${ }^{4}$ Asmadi Hassan, Rohayati Paidi, "Gerakan Penentangan Pemindahan Mcas Futenma ke Henoko di Okinawa, Jepun oleh All Okinawa Council.” Jebat: Malaysian Journal of History, Politics \& Strategic Studies, 2020, Vol. 47 (2), hlm. 79.

5 Tawara Yoshifumi, "What is the Aim of Nippon Kaigi, the Ultra-Right Organization that Supports Japan's Abe Administration?" The Asia-Pacific Journal, Vol. 15, No. 1, 2017, hlm. 2.

6 “Conservative Group behind Pro-Constitutional Amendment Petition Collecting,” Mainichi Japan, 4 May 2016.
} 
mencetuskan fenomena Nippon Kaigi Boom. ${ }^{7}$ Koichi Tsukamoto yang merupakan pengasas syarikat Wacoal adalah pengerusi pertama pertubuhan tersebut pada tahun 1997 hingga 1998. Pada masa sekarang Nippon Kaigi diketuai oleh Tadae Takubo, iaitu seorang profesor emeritus di Universiti Kyorin yang mengambil alih jawatan tersebut dari Ketua Hakim Mahkamah Agong, Toru Miyoshi pada tahun 2015. ${ }^{8}$ Pertubuhan ini mempunyai ibu pejabat di Tokyo dan 289 pejabat cawangan di seluruh todofuken (prefektur) dan daerah di Jepun. ${ }^{9}$ Pada tahun 2016 pertubuhan ini mempunyai keahlian berbayar seramai 38,000 orang menjadikan ia sebagai salah sebuah pertubuhan berhaluan kanan terbesar di Jepun. ${ }^{10}$ Selain itu keahlian juga mencakupi pelbagai peringkat dan sektor seperti syarikat swasta, ahli agama, presiden universiti, ketua SDF, ahli akademik dan ketua hakim.

Keahlian dari kalangan ahli politik berpengaruh terutamanya dari parti pemerintah, Parti Liberal Demokratik (LDP) turut menguatkan Nippon Kaigi. Antaranya adalah seperti Shinzo Abe, Taro Aso, Sanae Takaichi, Eriko Yamatani, Hakubun Shimomura, Wataru Takeshita, Seiichi Eto, dan sebagainya. Shinzo Abe dan Taro Aso masing-masing merupakan perdana menteri dan timbalan perdana menteri yang juga bertindak sebagai penasihat khas Nippon Kaigi. Sanae Takaichi pula merupakan ketua Majlis Penyelidikan Dasar LDP (PARC) yang juga menteri di Kementerian Dalam Negeri dan Komunikasi. Eriko Yamatani adalah menteri yang dilantik untuk menangani masalah berkaitan penculikan rakyat Jepun oleh Korea Utara yang juga merupakan ketua jawatankuasa dasar Nippon Kaigi. Selain itu Menteri Pendidikan Hakubun Shimomura yang juga Timbalan Ketua Nippon Kaigi dan Wataru Takeshita yang merupakan adik kepada bekas perdana menteri Noboru Takeshita merupakan menteri pembinaan semula bencana.

Kekuatan Nippon Kaigi ditambah dengan sejumlah 281 atau 39 peratus dari keseluruhan ahli parlimen menganggotai Nippon Kaigi. ${ }^{11}$ Manakala dari segi keanggotaan dalam kabinet pula, pada zaman pentadbiran Taro Aso tahun 2008, 10 dari 19 orang adalah dari kalangan ahli Nippon Kaigi $^{12}$ dan ketika pentadbiran Abe tahun 2014 jumlah itu meningkat kepada $15 .{ }^{13}$ Selain LDP, parti-parti lain juga menganggotai Nippon Kaigi seperti dari Kibo no To (Party of Hope) yang diketuai oleh Gabenor Tokyo Yuriko Koike, bekas Gabenor Tokyo Shintaro Ishihara dan Gabenor Osaka, Toru Hashimoto. Manakala ahli dari Parti Demokratik Jepun (DPJ) adalah seperti Bekas Menteri Luar Seiji Maehara, ${ }^{14}$ ahli Dewan Rendah Asako Omi, ${ }^{15}$ Hirofumi Ryu dan Akihisa Nagashima. Oleh itu dapat dikatakan bahawa pertubuhan ini menerima sokongan dari ramai ahli politik berhaluan kanan tanpa mengira parti. Namun disebabkan LDP merupakan parti yang dominan, maka orang ramai mengaitkannya dengan Nippon Kaigi.

Terdapat organisasi bersekutu dan organisasi yang menguruskan operasi harian bagi menjayakan sesuatu matlamat dalam Nippon Kaigi. Organisasi bersekutu adalah seperti Nippon Kaigi Kokkai Giin Kondankai (Nippon Kaigi Diet Members' League) dan Nippon Kaigi Chiho Giin Renmei (Nippon Kaigi Local Assembly Members' League). Manakala Nihon Josei No Kai

\footnotetext{
7 Tawara Yoshifumi. "What is the Aim of Nippon Kaigi," hlm. 1.

${ }^{8}$ Walter Sim, "Most Influential Right-wing Pressure Group in Japan.” The Straits Times, 2 May 2017.

${ }^{9}$ Reiji Yoshida, "Abe's Nationalism Reflected in Conservative Political Movement, but Polls Show Voter Dissent," The Japan Times, 14 Ogos 2015.

10 "Conservative Group behind Pro-Constitutional Amendment."

${ }^{11}$ Reiji Yoshida, "Abe's Nationalism."

12 "Pro-Yasukuni Lineup Features Aso Cabinet," Japan Press Weekly, 25 September 2008.

13 "Politics in Japan: Right Side Up," The Economist, 4 June 2015.

14 日本会議国会議員懇談会のメンバー (Ahli Nippon Kaigi dalam kalangan Anggota Majlis Mesyuarat Parlimen Jepun dari laman sesawang http://www.asyura2.com/09/senkyo70/msg/492.htm.

15 Ibid.
} 
(Japan Women's Association), Nihon Seinen Kyogikai (Japan Youth Council), Nihon Kyoiku Kaigi (Japan Education Conference), Kokusai Koho Iinkai (International Public Relations Committee for Broadcasting Japan's New Image to the World) dan Utsukushii Nippon no Kenpo wo Tsukuru Kokumin no Kai (National Citizens' Association to Create a Beautiful Constitution for Japan) merupakan organisasi yang menguruskan operasi harian bagi menjayakan sesuatu matlamat Nippon Kaigi.

Pertubuhan ini menggunakan slogan hokori aru kunizukuri e (ke arah membina negara yang dibanggakan). Dari slogan ini dapat difahami bahawa matlamat mereka adalah untuk membina sebuah negara Jepun yang penduduknya berbangga menjadi rakyat. Laman sesawang rasmi Nippon Kaigi (http://www.nipponkaigi.org/) menerangkan lebih mendalam tentang pertubuhan tersebut: watashi tachi ha utsukushi nihon no saiken to hokori aru kunizukuri no tame ni, seisaku teigen to kokumin undo wo suishin suru minkan dantai desu (kami adalah pertubuhan yang mencadangkan dasar dan mempromosikan pergerakan rakyat bagi membina semula keindahan dan kebanggaan Jepun). Dari kenyataan ini adalah tidak mengejutkan bahawa mereka sentiasa memperjuangkan dasar untuk membina semula keindahan dan kebanggaan menjadi rakyat Jepun. Dari laman sesawang Nippon Kaigi juga mereka menggariskan enam matlamat penubuhan iaitu:

1. Utsukushii dento no kunigara wo ashita no nihon e (Mewujudkan ciri-ciri keindahan budaya tradisi Jepun untuk masa depan).

2. Atarashii jidai ni fusawashii shinkenpo wo (Menggubal perlembagaan baharu berdasarkan persekitaran semasa yang sesuai).

3. Kuni no meiyo to kokumin no inochi wo mamoru seiji wo (Politik yang melindungi nama baik negara dan nyawa rakyat).

4. Nihon no kansei wo hagukumu kyouiku no souzou wo (Menggubal sistem pendidikan yang boleh melahirkan rakyat yang sentiasa peka).

5. Kuni no anzen wo takame sekai e no heiwa koken wo (Mewujudkan negara yang boleh menyumbangkan kepada keamanan dunia dengan menambahbaik keselamatan negara).

6. Kyosei kyoei no kokoro de musubu seikai to no yuko wo (Mewujudkan persahabatan di seluruh dunia dengan semangat kewujudan dan kemakmuran bersama).

Walaupun tidak secara langsung menggunakan nasionalisme dalam slogan dan matlamat pertubuhan ini, namun perkataan membina semula keindahan dan kebanggaan menjadi rakyat Jepun diterjemahkan sebagai untuk melahirkan rakyat Jepun yang cintakan negara (nasionalisme). Aktiviti yang dilakukan oleh kumpulan ini juga memperlihatkan kecenderungan semangat tersebut.

\section{KESONGSANGAN JEPUN}

Sachie Mizohata, ${ }^{16}$ memperincikan matlamat penubuhan Nippon Kaigi iaitu pertama bagi membina semula keindahan dan kebanggaan menjadi rakyat Jepun dengan mempromosikan kembali penyembahan rakyat kepada maharaja Jepun yang berketurunan lebih dari 125 generasi. Dengan kata lain, Nippon Kaigi mahu mengembalikan sistem kemaharajaan yang berasal usul dari tuhan matahari ke Jepun. Kedua, merombak semula perlembagaan yang digubal oleh penjajah dan masalah yang timbul akibat dari perlembagaan tersebut seperti halangan kepada kebebasan untuk melindungi keselamatan dan pertahanan negara dari ancaman asing dan digantikan dengan

\footnotetext{
${ }^{16}$ Sachie Mizohata, “Nippon Kaigi: Empire, Contradiction, and Japan's Future,” The Asia-Pacific Journal, Vol. 14,
} No. 4, 2016. 
perkara-perkara yang lebih sesuai dengan keadaan semasa. Ketiga, memulihkan kembali nama baik Jepun dengan menekankan kepada kepentingan, reputasi dan kedaulatan negara, termasuk memberi penghormatan kepada mereka yang meninggal demi negara yang disemadikan di kuil Yasukuni. Keempat, memupuk golongan muda dengan semangat patriotisme melalui penghormatan kepada sejarah, lagu dan bendera kebangsaan. Pelaksanaan matlamat ini adalah melalui perubahan dalam sistem pendidikan, terutamanya dalam mata pelajaran sejarah dan pendidikan moral. Kelima, memperkukuhkan Tentera Pertahanan Diri (SDF) supaya dapat bersama-sama negara lain memikul tanggungjawab kepimpinan global dan mengimbangi ancaman yang ditimbulkan oleh China dan Korea Utara. Terakhir, membina hubungan mesra dengan negara lain melalui program pertukaran dan bantuan pembangunan.

Pertubuhan ini dilihat menongkah arus dengan percubaan untuk mencetuskan perubahan status quo dalam sistem negara, terutamanya bagi membina semangat nasionalisme rakyat terhadap negara. Dari enam matlamat yang dinyatakan oleh Nippon Kaigi, jelas bahawa pertubuhan tersebut menetapkan bahawa Jepun perlu berubah dari kesongsangan yang ada sekarang kepada sebuah negara yang boleh dibanggakan dari dalam dan luar negara dengan aspek nasionalisme ditekankan ke dalam diri setiap rakyatnya.

\section{STATUS MAHARAJA}

Nippon Kaigi berpendapat bahawa maharaja perlu dihormati dengan diangkat sebagai pemerintah negara seperti pada zaman sebelum perang. ${ }^{17}$ Perkara ini bertentangan dengan status maharaja pada masa sekarang iaitu hanyalah sebagai raja berperlembagaan yang menjalankan tugas-tugas yang telah ditetapkan dengan nasihat daripada Perdana Menteri. Aktivis Nippon Kaigi terkenal, Yoshiko Sakurai, yang merupakan pencetus kepada pergerakan revisionis menerangkan kepentingan sistem maharaja sebagai,

Japan has a unique (dokuji) civilization that has developed since olden times. (...) While the royal families of other countries have achieved their position through the use of military or financial power and integrated the state through the exercise of power and authority, the Japanese imperial family has its origins in the age of the myths and, based on the spirit of the Japanese people (Nihonjin no kokoro), it has become the central force making for national unity. (...) The most important factor that has contributed to the formation of the Japanese national character (kunigara) and the qualities of the Japanese people is nothing other than the spiritual unity created by the Imperial House. ${ }^{18}$

Dari pernyataan Sakurai didapati bahawa maharaja Jepun memperolehi kedudukannya melalui mitos dan berdasarkan semangat rakyat Jepun. Ini menunjukkan ketinggian kedudukan dan kesucian maharaja Jepun berbanding maharaja di negara lain yang menduduki takhta melalui penggunaan ketenteraan atau kekayaan. Kedudukan maharaja juga dihormati kerana baginda

\footnotetext{
${ }^{17}$ Matthew Penney, “The Abe Cabinet - An Ideological Breakdown,” The Asia-Pacific Journal. Vol. 10, No. 137, 2012.

${ }^{18}$ Sven Saaler, "Nationalism and History in Contemporary Japan.” The Asia-Pacific Journal, Vol. 14, No. 7, 2016.
} 
merupakan simbol perpaduan negara yang menyumbangkan kepada pembentukan identiti negara bangsa Jepun. Nippon Kaigi menekankan semangat maharaja di mana pada zaman perang ia digunakan sebagai alat untuk untuk mendapatkan kesetiaan dan kesediaan rakyat untuk berkorban demi negara. Semangat tersebut diperlukan pada masa sekarang bagi membangunkan kecintaan kepada negara melalui penghormatan kepada maharaja. Oleh itu Sakurai berpendapat bahawa kedudukan maharaja perlu diangkat lebih tinggi seperti pada zaman sebelum perang, iaitu sebelum pembaharuan dilakukan oleh Amerika Syarikat ke atas institusi kemaharajaan Jepun.

\section{PERLEMBAGAAN}

Setiausaha Agong, Yuzo Kabashima yang juga digelar commander in chief dalam Nippon Kaigi mengatakan bahawa Perlembagaan Empayar Jepun mempunyai mukadimah jelas yang menunjukkan penghormatan kepada keluarga maharaja dan orang Jepun yang meninggal dunia. Walau bagaimanapun, mukadimah perlembagaan sekarang tidak menghormati tradisi tersebut, sebaliknya rakyat Jepun telah menjadi orang bukan Jepun kerana perlembagaan sekarang. ${ }^{19}$ Perlembagaan tersebut tidak menghormati Jepun sebagai sebuah negara merdeka kerana tidak menggambarkan tentang persekitaran politik, ekonomi, sosial dan budaya orang Jepun yang sebenarnya. Jepun memerlukan perlembagaan yang mencerminkan semangat kejepunan ${ }^{20}$ kerana perlembagaan sekarang yang merupakan dokumen perundangan terpenting negara digubal oleh pihak luar yang tidak memahami tentang Jepun, sebaliknya lebih kepada kebaratan. Pertubuhan ini mendesak supaya perlembagaan dirombak semula bagi mengembalikan kehormatan Jepun di mata dunia. Nippon Kaigi melihat demokrasi, hak asasi manusia dan kebebasan individu sebagai hasil dari idea barat yang tidak relevan dengan nilai dan ciri-ciri Jepun. Bagi mereka pemikiran barat perlu digantikan dengan order sosial Jepun yang spesifik dan tradisional berasaskan kemaharajaan. Dengan kata lain perlembagaan yang digubal hendaklah meletakkan kepentingan negara melebihi kepentingan individu seperti pada zaman perang yang menyaksikan kesediaan rakyat berkorban demi negara. ${ }^{21}$

Selain itu mereka melihat perkara utama dalam perlembagaan yang perlu diubah adalah Perkara 9. Yoshiko Sakurai menolak klausa pasifis Perkara 9 dalam perlembagaan yang membataskan aktiviti ketenteraan Jepun sebagai sebuah negara berdaulat. ${ }^{22}$ Sakurai menegaskan bahawa perlembagaan sekarang tidak melindungi rakyat dan negara sekiranya diserang, tetapi terpaksa bergantung kepada pihak luar, iaitu Amerika Syarikat. Manakala penasihat dan jurucakap Nippon Kaigi, Akira Momochi menegaskan bahawa Jepun perlu menjadi sebuah negara normal, iaitu mengembalikan Jepun sebagai sebuah negara bebas dengan menghapuskan legasi pasca Perang Dunia Kedua yang menyekat aktiviti tentera Jepun dari dihantar ke luar negara. ${ }^{23}$ Kenyataan ini disokong oleh Yoshiko Sakurai ${ }^{24}$ yang menambah bahawa negara normal yang dikehendaki Jepun boleh menggunakan ketenteraannya sendiri bagi melindungi kepentingan negara. Dengan kebebasan sepenuhnya dalam ketenteraan, Jepun dapat menangani ancaman dan menggagalkan sebarang percubaan untuk memerangi negara termasuk melindungi sekutu

\footnotetext{
${ }^{19}$ Koji Sonoda, “Japan Conference’s Quest for Constitutional Revision,” The Japan Times, 7 June 2016.

${ }^{20}$ Matthew Carney, "Nippon Kaigi: the Ultra-Nationalistic Group Trying to Restore the Might of the Japanese Empire," ABC News, 2 December 2015.

${ }^{21}$ Sachie Mizohata, "Nippon Kaigi: Empire, Contradiction, and Japan’s Future.”

${ }^{22}$ Kim Hyun-ki, “Nationalist 'Japan Conference’ Building its Clout,” Korea JoonAng Daily. 3 May 2013.

${ }^{23}$ Adam P. Liff. 2015. Japan's defense policy: Abe the evolutionary. The Washington Quarterly 38(2): hlm. $79-89$.

24 "Politics in Japan."
} 
terdekatnya. ${ }^{25}$ Adalah lebih sesuai bagi sesebuah negara merdeka mempunyai tentera sendiri dan tidak terikat dengan kekangan seperti yang ditetapkan oleh perlembagaan. Tadae Takubo pula menegaskan kebangkitan China sebagai kuasa tentera dan hubungan diplomatik tidak stabil dengan Korea Selatan dan Utara menimbulkan kebimbangan dalam kalangan orang awam. ${ }^{26}$ Oleh itu Nippon Kaigi perlu berusaha untuk meminda perlembagaan bagi membolehkan halangan kepada penggunaan sepenuhnya Tentera Pertahanan Diri Jepun (SDF) dihapuskan.

Tambahan lagi kebelakangan ini sentimen negatif rakyat Jepun terhadap China dan Korea Selatan telah meningkat seperti ditunjukkan dalam kajian yang dijalankan oleh Pejabat Kabinet Jepun (Kantei). Kajian pada tahun 2014 mendapati bahawa 93\% responden Jepun mempunyai sentimen negatif terhadap China apabila negara tersebut mula mengancam Jepun. Peningkatan sentimen negatif berlaku sejak tahun 2000-an apabila Koizumi mengadakan lawatan ke Kuil Yasukuni setiap tahun dan pada tahun 2010-an berikutan ketegangan tuntutan bertindih ke atas kepulauan Senkaku di Laut China Timur memuncak. Manakala kajian pada tahun 2014 juga mendapati $66.4 \%$ rakyat Jepun mempunyai sentimen negatif terhadap Korea Selatan. Sentimen positif ke atas Korea Selatan jatuh pada tahun 2012 berikutan lawatan Presiden Lee Myungbak ke kepulauan Takeshima iaitu pulau yang menjadi rebutan antara Jepun dengan Korea Selatan. ${ }^{27}$ Sehubungan itu Nippon Kaigi juga mengambil pendirian provokatif terhadap jiran sekitarnya dengan mempertahankan Senkaku dan Takeshima yang dituntut juga oleh China dan Korea Selatan. ${ }^{28}$

\section{PEMULIHAN NAMA BAIK DAN KEBEBASAN JEPUN}

Memulihkan kembali nama baik Jepun juga penting bagi Nippon Kaigi. Imej Jepun yang tercemar terutamanya berkaitan dengan peristiwa lampau semasa Perang Dunia Kedua perlu dibersihkan. Jepun dianggap sebagai sebuah negara yang melakukan kekejaman ke atas negara yang dijajahinya terutamanya di China dan Semenanjung Korea. Antaranya adalah memaksa rakyat negara tersebut bekerja di syarikat-syarikat Jepun tanpa dibayar gaji dan menjadi hamba seks kepada tentera Jepun. Selain itu kebebasan bertindak Jepun seringkali dipertikaikan oleh negara asing seperti dalam isu lawatan ke Kuil Yasukuni, kuil yang menempatkan roh mereka yang mati kerana negara. Nippon Kaigi menegaskan bahawa menghormati mereka yang mati kerana negara termasuk mereka yang dianggap sebagai penjenayah perang sebagai tanggungjawab negara. Pertubuhan ini mahukan rakyat dan pemimpin Jepun termasuk perdana menteri bebas melawat Kuil Yasukuni tanpa ada halangan dari negara jirannya. ${ }^{29}$ Permulaan penentangan lawatan ke Kuil Yasukuni adalah pada 15 Ogos 1985 apabila perdana menteri Yasuhiro Nakasone mengadakan lawatan bagi mengingati 40 tahun berakhirnya Perang Dunia Kedua. Kerajaan China memprotes lawatan tersebut dengan menegaskan bahawa perdana menteri mengagongkan penjenayah kelas A yang turut disemadikan di situ. ${ }^{30}$ Selepas lawatan tersebut tidak ada lagi perdana menteri sehingga Junichiro Koizumi

\footnotetext{
${ }^{25}$ The Japan Times. 2014. Protecting the peace constitution. 2 May.

${ }^{26}$ Reiji Yoshida. "Abe's Nationalism."

27 Koichi Nakano, “Contemporary Political Dynamics of Japanese Nationalism," The Asia-Pacific Journal, Vol. 14. No. 6, 2016.

${ }^{28}$ Yuji Sasagase, Keita Hayashi, Sato Kei, “Japan's Largest Rightwing Organization: An Introduction to Nippon Kaigi," The Asia-Pacific Journal, Vol. 13, No. 5, 2015.

${ }^{29}$ Politics in Japan: Right side up. The Economist. 4 Jun 2015.

${ }^{30}$ Asmadi Hassan, 'Nippon Izokukai and the Controversial Visit of the Japanese Prime Minister to the Yasukuni Shrine,' in Muhammad Danial Azman \& Geetha Govindasamy, Insight to East Asia: Bridging the Past and Present, Kuala Lumpur: University of Malaya Press, 2018. hal. 75-88.
} 
mengadakan lawatan setiap tahun pada 2001 hingga 2006 dan Shinzo Abe pada tahun 2013 yang juga menimbulkan kemarahan China dan Korea. ${ }^{31}$ Biarpun alasan yang diberikan adalah untuk memberi penghormatan kepada mereka yang terkorban kerana negara, namun kedua-dua negara tersebut kekal dengan pendirian mengecam lawatan perdana menteri ke Kuil Yasukuni.

\section{SISTEM PENDIDIKAN PATRIOTIK}

Nippon Kaigi juga mendapati bahawa pada masa sekarang semangat nasionalisme dalam kalangan rakyat Jepun adalah sangat rendah berbanding negara-negara yang lain. Kerendahan semangat nasionalisme dikaitkan dengan pengajaran sejarah Jepun di sekolah yang memburukkan negara kepada pelajar. Sistem pendidikan yang diguna menyebabkan orang Jepun malu dengan sejarah negara mereka sendiri. ${ }^{32}$ Nippon Kaigi berpendirian bahawa mengajar tentang keindahan Jepun adalah lebih baik yang bermaksud mengajar "sejarah yang betul supaya golongan muda berbangga jadi rakyat Jepun." 33 Nippon Kaigi menolak beberapa fakta sejarah yang dianggap menyeleweng dari fakta yang sebenar dan perlu diperbetulkan. Contohnya Jepun wajar diberi penghargaan kerana penglibatan dalam peperangan adalah untuk membebaskan negara-negara Asia dari kolonialisme barat dan bukan berperang kerana keganasan. ${ }^{34}$ Oleh itu negara-negara ini bergantung kepada Jepun untuk kemerdekaan dari kolonialisme barat. Peperangan dengan kuasa barat merupakan sumbangan antarabangsa Jepun yang terbaik dan menjadi contoh kepada pengorbanan dalam sejarah kemanusiaan. ${ }^{35}$

Nippon Kaigi juga menolak pembunuhan beramai-ramai oleh tentera Imperial Jepun di Nanking pada tahun 1937 yang dianggar melibatkan 200,000 orang. ${ }^{36}$ Pertubuhan ini menganggap peristiwa itu sengaja diperbesarkan bagi memburukkan imej Jepun. ${ }^{37}$ Manakala penghakiman terhadap penjenayah perang Kelas A oleh Tribunal Penjenayah Perang Tokyo tahun 1946-1948 dianggap sebagai tidak sah. Sebaliknya Nippon Kaigi menegaskan bahawa kematian lebih 300,000 orang dalam tragedi bom atom di Hiroshima dan Nagasaki merupakan pembunuhan beramai-ramai manusia yang tidak berdosa. Perbicaraan penjenayah perang Tokyo dijalankan hanya untuk menutup pembunuhan beramai-ramai di kedua-dua bandar tersebut. ${ }^{38}$

Nippon Kaigi juga seringkali mencabar kenyataan permohonan maaf perdana menteri Tomiichi Murayama tentang penaklukan dan keganasan semasa perang dan permohonan maaf Ketua Setiausaha Kabinet Yohei Kono pada tahun 1993, berkaitan penglibatan secara langsung dan tidak langsung tentera Jepun dalam penubuhan dan pengurusan perhambaan seks semasa Perang Dunia Kedua. ${ }^{39}$ Kenyataan Yohei Kono,

Comfort stations were operated in response to the request of the military authorities of the day. The then Japanese

\footnotetext{
${ }^{31}$ Koichi,Nakano, "Contemporary Political Dynamics of Japanese Nationalism."

${ }^{32}$ Koji Sonoda, "Japan Conference's Quest for Constitutional Revision."

${ }^{33}$ Walter Sim, "Most Influential Right-wing Pressure Group in Japan."

${ }^{34}$ Matthew Carney, "Nippon Kaigi."

${ }^{35}$ Sven Saaler, "Nationalism and History in Contemporary Japan."

${ }^{36}$ Matthew Carney, "Nippon Kaigi."

${ }^{37}$ Walter Sim, "Most Influential Right-wing Pressure Group in Japan."

${ }^{38}$ David McNeill, "Nippon Kaigi and the Radical Conservative Project to Take Back Japan," The Asia-Pacific Journal. Vol 13, No 4, 2015.

${ }^{39}$ Weiss Andrew, "Towards a Beautiful Japan: Right-Wing Religious Nationalism in Japan's LDP", Eli Scholar, 2018.. Rujuk juga “Japan’s 'Comfort Women' “Analysis, 14 January 2018.
} 
military was, directly or indirectly, involved in the establishment and management of the comfort stations and the transfer of comfort women. The recruitment of the comfort women was conducted mainly by private recruiters who acted in response to the request of the military. The Government study has revealed that in many cases they were recruited against their own will, through coaxing, coercion, etc., and that, at times administrative/military personnel directly took part in the recruitments. They lived in misery at comfort stations under a coercive atmosphere. ${ }^{40}$

Kenyataan Kono dikritik kerana tiada bukti mencukupi, sebaliknya ia menganggap sebagai satu sistem pelacuran pada zaman perang. ${ }^{41}$ Nippon Kaigi meminta supaya sejarah ditulis semula kerana percaya ia akan mengembalikan kebanggaan menjadi rakyat Jepun. Rakyat Jepun telah lama didoktrinkan oleh sejarah lampau sehingga menyebabkan mereka malu dengan sejarah mereka sendiri. Ringkasnya, Nippon Kaigi berkempen menentang sesuatu yang memburukkan tingkah laku Jepun semasa zaman perang dan memasukkan ideologi nasionalisme dalam kalangan pelajar yang selama ini didoktrinkan dengan keburukan sejarah lampau.

\section{GERAKAN MEMBANGKITKAN NASIONALISME}

Antara aktiviti yang dijalankan bagi menjayakan matlamat Nippon Kaigi adalah mengumpul tandatangan di seluruh negara, mengadakan perjumpaan di tempat-tempat tumpuan ramai dan kumpulan-kumpulan kecil seluruh negara, menerbitkan majalah, mengedarkan risalah dan DVD serta melancarkan video perjuangan mereka di media sosial. Contohnya Nippon no Ibuki (Breath of the Nation) merupakan majalah yang diterbitkan bagi mengetengahkan secara khusus perjuangan mereka seperti penolakan peristiwa Nanking dan perbicaraan Tokyo ke atas penjenayah perang Jepun sebagai tidak sah. Selain itu bagi mendapatkan sokongan ramai, ahli politik yang menganggotai pertubuhan tersebut turut menyertai aktiviti yang dianjurkan. Penglibatan ahli politik bukan sahaja dapat menarik rakyat untuk turut serta, tetapi lebih penting adalah kuasa yang dimiliki sebagai pembuat dasar dapat mengubah dasar sedia ada mengikut kehendak kumpulan tersebut.

Dalam isu kebebasan melawat ke Kuil Yasukuni, Nippon Kaigi berpendirian tegas bahawa ia adalah hak rakyat Jepun dan tiada negara lain yang boleh menghalang mereka berbuat demikian. Bagi membuktikan ketegasan mereka pada April 2013 semasa pesta musim bunga, empat orang ahli kabinet Abe yang juga ahli Nippon Kaigi iaitu Taro Aso, Menteri di Kementerian dalam Negeri dan Komunikasi Shindo Yoshitaka, Ketua Suruhanjaya Keselamatan Am Kebangsaan Keiji Furuya dan Menteri untuk Pembaharuan Pentadbiran dan Kakitangan Kerajaan Tomomi Inada melawat Kuil Yasukuni. Pada bulan yang sama, 170 orang ahli diet yang majoritinya ahli Nippon Kaigi melakukan lawatan ke Kuil Yasukuni bagi menjalankan upacara memperingati

\footnotetext{
${ }^{40}$ Norma Field, Tomomi Yamaguchi, "Comfort Woman' Revisionism Comes to the U.S.: Symposium on the Revisionist Film Screening Event at Central Washington University," The Asia-Pacific Journal, Vol. 13, No. 1, 2015.

${ }^{41}$ Karoline Postel-Vinay, Sciences Po, "The Global Rightist Turn, Nationalism and Japan," The Asia-Pacific Journal. Vol. 15, No. 1, 2017. Hlm, 11.
} 
mereka yang terkorban demi negara termasuk penjenayah Perang Kelas A. ${ }^{42}$ Pada tahun berikutnya, 100 orang ahli Diet termasuk 3 menteri melawat Yasukuni, ${ }^{43} 80$ orang termasuk seorang menteri pada tahun $2016,{ }^{44} 63$ orang pada tahun $2017,{ }^{45} 50$ orang pada tahun $2018,{ }^{46}$ dan 70 orang pada tahun 2019. ${ }^{47}$ Tindakan melawat kuil Yasukuni membuktikan ahli politik yang mengganggotai Nippon Kaigi tidak mengambil kira tentangan dari pihak luar dan berterusan mengagongkan mereka yang meninggal dunia kerana negara. Ini merupakan kejayaan pertubuhan tersebut walaupun masih terdapat beberapa orang pemimpin berpengaruh teragak-agak melakukan lawatan tersebut termasuk perdana menteri. Walaupun Shinzo Abe telah melakukan lawatan pada tahun 2013, tetapi beliau menghentikan lawatan selepas dikritik hebat oleh negara jirannya. Namun beliau masih lagi menderma wang peribadi bagi melakukan upacara memperingati roh yang ada di Kuil Yasukuni sehingga ke hari ini ${ }^{48}$ yang menunjukkan semangat yang kuat serta penghormatan yang tinggi kepada mereka yang meninggal demi negara. ${ }^{49}$

Manakala dalam usaha menjayakan matlamat rombakan perlembagaan, pada November 2013, Nippon Kaigi mengadakan konvensyen yang dihadiri oleh 800 peserta dari seluruh negara. Konvensyen bertajuk Bring About Constitutional Revision meluluskan resolusi rombakan perlembagaan melalui referendum rakyat. Sehubungan itu pada tahun 2014 National Citizens' Association to Create a Beautiful Constitution for Japan ditubuhkan khas bagi merombak perlembagaan berdasarkan referendum. Pelbagai aktiviti dianjurkan oleh pertubuhan ini termasuk yang berskala besar. Contohnya pada November 2015, 11,000 orang hadir ke Dewan Nippon Budokan di Tokyo untuk menuntut rombakan perlembagaan dijalankan dengan segera. ${ }^{50}$ Ahli politik yang hadir adalah seperti Seiichi Eto yang juga merupakan penasihat khas Shinzo Abe, Hakubun Shimomura, ketua Nippon Kaigi Diet Members' League Takeo Hiranuma, Haruko Arimura dan Junko Mihara. ${ }^{51}$ Aktiviti yang dijalankan adalah mengumpul tandatangan di mana sasarannya yang ditetapkan adalah 10 juta orang. Pada masa perhimpunan dijalankan 4.5 juta tandatangan telah diperolehi. Walaupun Shinzo Abe tidak menghadiri ke perhimpunan tersebut, tetapi beliau turut memberi sokongan rombakan perlembagaan melalui panggilan video dalam perhimpunan tersebut. ${ }^{52}$

Manakala pada Mei 2016, pertubuhan ini menganjurkan forum umum berkaitan perlembagaan bertajuk Calling for an Initiative to Realize Speedy Revision of the Constitution! yang dihadiri oleh 1200 orang peserta. Forum tersebut menyeru supaya semua orang bersatu untuk merombak semula perlembagaan. Manakala pada Ogos 2017, pertubuhan ini mengadakan pameran berhampiran Kuil Yasukuni. Pameran tersebut turut mempamerkan bendera dan papan

\footnotetext{
42 Kim Hyun-ki, "Nationalist 'Japan Conference' Building its Clout.”

43 “3 Japan Cabinet ministers Visit Controversial Yasukuni Shrine a Day after PM Abe's Offering," The Straits Times, 18 October 2014.

44 "Japanese Politicians Upset South Korea with Visit to Yasukuni Shrine," The Guardian, 18 Oktober 2016.

45 "No Cabinet Members Visited Yasukuni Shrine on War Anniversary," Mainichi Japan, 16 August 2017.

46 “Japan PM Abe refrains from visiting Yasukuni Shrine on WWII Anniversary," Nikkei Asian Review, 15 August 2018.

47 “Cross-party Group of Around 70 Lawmakers Visits Japan's War-Linked Yasukuni Shrine,” The Japan Times, 23 April 2019.

48 “Japanese Lawmakers Visit War-Linked Yasukuni Shrine. Kyodo News, 23 April 2019.

49 "No Cabinet Members Visited Yasukuni Shrine on War Anniversary."

${ }^{50}$ Reiji Yoshida, “Thousands Rally in Nippon Budokan Hall for Constitutional Change," The Japan Times, 10 November 2015.

${ }^{51}$ David McNeill, "Nippon Kaigi and the Radical Conservative Project to Take Back Japan."

${ }^{52}$ Kim Hyun-ki, "Nationalist 'Japan Conference' Building its Clout."
} 
tanda Write the SDF into the Constitution dan Thank you, $S D F .{ }^{53}$ Memasukkan perkataan SDF ke dalam perlembagaan adalah bertujuan untuk memastikan keabsahan kewujudan angkatan tentera Jepun kerana selama ini terdapat kritikan yang mempersoalkan kewujudan mereka sebagai melanggar perlembagaan Jepun. ${ }^{54}$ Ia juga merupakan langkah awal untuk menjadikan SDF sebagai tentera normal yang boleh digerakkan ke mana sahaja apabila diperlukan.

Selain itu organisasi wanita, Japan Women's Association yang diketuai oleh Aiko Anzai yang juga merupakan timbalan pengerusi Nippon Kaigi turut memainkan peranan penting. Sayap wanita turut serta berkempen untuk membuat perubahan dalam perlembagaan di mana kumpulan sasaran mereka adalah golongan wanita. Kumpulan ini membuka kafe di seluruh negara di mana wanita boleh bersama-sama berbincang tentang perlembagaan. Namun lebih penting lagi pertubuhan ini berfungsi matlamat untuk mengdoktrin wanita lain supaya menyokong perjuangan merombak semula perlembagaan.

Dalam aspek pendidikan pula, matlamat pentadbiran Abe adalah untuk membangunkan semula pendidikan bagi melahirkan pelajar cintakan negara serta masyarakat yang dinamik. Sistem pendidikan ini menyasarkan rakyat bersedia untuk berkhidmat kepada negara bila-bila masa diperlukan. Pembaharuan utama termasuk mengukuhkan kawalan ke atas kandungan pendidikan dan pentadbiran sekolah serta guru. Sehubungan itu organisasi bersekutu Nippon Kaigi dalam parlimen, Nippon Kaigi Diet Members' League bekerjasama dengan ahli Diet dan menjalankan kerja melobi bagi merombak semula undang-undang pendidikan Jepun iaitu Kyoiku Kihon Ho (Undang-undang Pendidikan Asas). Pada tahun 2006 rombakan Undang-undang Pendidikan Asas telah berjaya diluluskan dan menjadi undang-undang untuk sistem pendidikan Jepun. Antara kandungannya adalah memperkenalkan pendidikan moral, membawa unsur patriotisme ke sekolah, menghapuskan sejarah masokistik dan mewujudkan persekitaran pendidikan yang lebih kompetitif. Abe menyedari tentang permasalahan patriotisme dalam pendidikan dan berpendapat bahawa memberi kebanggaan pelajar yang dilahirkan di Jepun adalah satu keperluan. Oleh itu prinsip asas pendidikan haruslah melahirkan pelajar yang berbangga menjadi rakyat Jepun dan dihormati oleh dunia. Jepun tidak boleh menyalahkan diri sendiri dan pelajar perlu diajar dengan sejarah betul yang penuh dengan kebanggaan. ${ }^{55}$ Usaha mempromosikan penggunaan buku teks baharu yang memulihkan kembali imej Jepun giat dijalankan. Ini seterusnya membawa kepada perubahan dalam kandungan buku teks sejarah. ${ }^{56}$ Hasilnya, pada tahun 2006, kesemua rujukan kepada perhambaan seks telah dihapuskan dalam buku teks yang diluluskan oleh kerajaan. ${ }^{57}$

Selain itu, video animasi bertajuk Hokori (Pride) telah diedarkan kepada sekolah-sekolah awam di bawah naungan Kementerian Pendidikan pada tahun 2007. Ia dihasilkan oleh Japan Youth Council sebagai sebahagian daripada Program for the Development of a New Educational System (Program Pembangunan Sistem Baharu Pendidikan). Video tersebut mengandungi adegan roh seorang askar yang telah meninggal mengajak seorang gadis sekolah tinggi ke Kuil Yasukuni untuk mengenang mereka yang meninggal dunia kerana mempertahankan negara. Berkaitan dengan ini juga, Kementerian Pendidikan telah mengumumkan pada 27 Mac 2008 penarikan balik peraturan yang mengharamkan lawatan sekolah ke Kuil Yasukuni oleh Pihak Pendudukan pada tahun 1945 dan peraturan Kementerian Pendidikan pada tahun 1949. Kementerian menjelaskan

\footnotetext{
53 Yoshiko Sakurai. “Can LDP Manage to Consolidate Proposals for Revision of Article 9 of Japan's Pacifist Constitution?," The Weekly Shincho, No. 794, 15 March 2018.

${ }^{54}$ Yoshiko Sakurai, "Hostile Anti-Abe Media Hampering Constitutional Revision” The Weekly Shincho, No. 797, 5 April 2018.

${ }^{55}$ Matthew Penney, "The Abe Cabinet - An Ideological Breakdown.” hlm. 6.

${ }^{56}$ Sven Saaler, "Nationalism and History in Contemporary Japan," hlm. 12.

${ }^{57}$ Koichi Nakano, "Contemporary Political Dynamics of Japanese Nationalism," hlm. 3.
} 
bahawa sekolah-sekolah kini dibenarkan menguruskan lawatan ke tempat tersebut sebagai sebahagian daripada program pendidikan. ${ }^{58}$

Selain di Parlimen, kumpulan tersebut turut melobi organisasi di peringkat kerajaan tempatan melalui Nippon Kaigi Local Assembly Members' League. Organisasi tersebut bekerjasama dalam memilih buku teks semasa sesi dewan perhimpunan tempatan sedang berlangsung. Pada tahun 2014, ubah suai Board of Education System yang membolehkan gabenor dan datuk bandar campur tangan dalam proses pemilihan buku teks yang bersifat revisionis telah dijalankan. ${ }^{59}$ Di bawah sistem ini Nippon Kaigi Local Assembly Members' League memainkan peranan dalam mempromosikan buku teks sejarah yang diterbitkan oleh penerbit yang dipilih oleh mereka seperti Ikuhosha dan Jiyusha iaitu penerbit yang menyokong pembaharuan dalam pendidikan. ${ }^{60}$ Kandungan buku teks Ikuhosha juga mencerminkan keutamaan pentadbiran Abe dalam sistem pendidikan Jepun. ${ }^{61}$

Dalam isu berkaitan menghormati bendera dan lagu kebangsaan, Hinomaru dan Kimigayo, kerajaan telah meluluskan pada tahun 1999 sebagai simbol rasmi negara walaupun dikaitkan dengan legasi perang. ${ }^{62}$ Gerakan di balik tabir dijalankan oleh dewan kerajaan tempatan dengan pejabat cawangan Nippon Kaigi seluruh negara bagi semua sekolah rendah dan menengah mengibarkan Hinomaru setiap hari. Contohnya, petisyen diedarkan oleh pejabat cawangan Nippon Kaigi pada tahun 2013 di Nakano Ward, Tokyo yang mendesak supaya semua sekolah berbuat demikian. Tiga ahli dewan perwakilan tempatan di Tokyo yang juga ahli Nippon Kaigi Local Assembly Members' League mengedarkan petisyen dan kerja-kerja memujuk ahli dewan tempatan lain untuk menyokongnya. Akhirnya kelulusan diperolehi dan petisyen telah berjaya. ${ }^{63}$ Kementerian Pendidikan mengeluarkan garis panduan dan arahan untuk semua sekolah awam untuk menyanyikan lagu kebangsaan dan menggunakan bendera untuk acara rasmi, seperti upacara masuk dan tamat pengajian. Nippon Kaigi juga mendesak supaya tindakan disiplin diambil dengan memindahkan, mendenda dan menahan kerja guru berhaluan kiri yang mengajar tentang keburukan sejarah Jepun.

Di satu sudut yang lain, personaliti yang sangat mementingkan penghormatan lagu Kimigayo dan bendera Hinomaru adalah Shintaro Ishihara dan Toru Hashimoto. Kedua-dua gabenor ini menyokong untuk menghukum guru-guru yang enggan berdiri dan melihat bendera serta menyanyikan lagu tersebut. ${ }^{64}$ Malahan Hashimoto dalam Twitter mengatakan:

What is beneficial for the students is more important than freedom of conscience for the stupid teachers (baka kyōin). The teachers at public schools are public servants of Japan. They make their living off of our taxes. If they don't like the national flag and anthem, they should resign from their position. There is freedom not to stand and refrain from

\footnotetext{
${ }^{58}$ Mark R. Mullins, "The Neo-Nationalist Response to the Aum Crisis A Return of Civil Religion and Coercion in the Public Sphere?” Japanese Journal of Religious Studies, Vol. 39, No. 1, hal. 120.

59 Tawara Yoshifumi, "What is the Aim of Nippon Kaigi," hlm. 14.

${ }^{60}$ Ibid, hlm. 14.

61 Tomomi Yamaguch, "The "Japan Is Great!" Boom, Historical Revisionism, and the Government," The AsiaPacific Journal, Vol. 15, No. 3, 2017, hlm. 3.

${ }^{62}$ Mark R. Mullins, "Neonationalism, Religion, and Patriotic Education in Post Disaster Japan," The Asia-Pacific Journal, Vol. 14, No. 5, 2016.

${ }^{63}$ Tawara Yoshifumi. "What is the Aim of Nippon Kaigi," hlm. 15.

${ }^{64}$ Mark R. Mullins, "Neonationalism, Religion, and Patriotic Education in Post Disaster Japan."
} 
singing the national anthem, but only for citizens who are not public servants (kōmuin). ${ }^{65}$

Nippon Kaigi juga bergerak untuk menghapuskan perkara-perkara yang memalukan imej Jepun di mata dunia. Pada Jun 2012, Nippon Kaigi berjaya mengumpul lebih dari 28,000 tandatangan sebagai petisyen kepada Rumah Putih yang meminta campur tangan Presiden Obama supaya menurunkan monumen di New Jersey, Amerika Syarikat yang didedikasikan kepada memori hamba seks Korea yang diculik dan dirogol oleh tentera Jepun. Petisyen tersebut menggambarkan pembinaan monumen sebagai memalukan rakyat Jepun dan sebagai tuduhan palsu berkaitan isu hamba seks Korea. Petisyen tersebut juga disokong oleh Eriko Yamatani dan Keiji Furuya dan keluarga mangsa penculikan rakyat Jepun oleh Korea Utara pada tahun 1970-an dan 1980-an. Manakala dalam negara pula, satu Dewan Perwakilan di Gumma telah tiga kali mengadakan petisyen yang meminta supaya monumen yang dipanggil "Gumma no Mori" di Bandar Takasaki yang ditujukan kepada buruh paksa Korea dirobohkan. ${ }^{66}$ Orang Korea telah dibawa secara paksa ke Jepun untuk bekerja di lombong dan pembinaan di kawasan monumen tersebut dibina. Ahli dewan perwakilan yang memainkan peranan dalam mengadakan petisyen ini adalah Manami Kazutaka dan Karino Masashi yang juga merupakan ahli Nippon Kaigi di peringkat kerajaan tempatan.

\section{ANALISIS}

Nippon Kaigi berjaya mencapai beberapa matlamat yang diperjuangkan bukan sahaja kerana kekuatan yang dimiliki pertubuhan tersebut tetapi keanggotaanya yang terdiri dari pelbagai lapisan masyarakat terutamanya dalam kalangan ahli politik berpengaruh. Dengan adanya golongan tersebut dalam Nippon Kaigi memudahkan lagi perjuangan mereka. Tambahan lagi perjuangan yang disasarkan adalah selari dengan yang dituntut oleh ahli politik tersebut terutamanya pemimpin tertinggi LDP Shinzo Abe. ${ }^{67}$ Contoh pendirian Abe yang selari dengan Nippon Kaigi adalah dalam isu keganasan Jepun semasa Perang Dunia Kedua. Pada tahun 1993, setelah Abe dipilih sebagai ahli parlimen kali pertama, beliau telah dilantik menganggotai Jawatankuasa History and Deliberation Committee LDP. Jawatankuasa ini mengadakan 20 pertemuan dengan pakar sejarah berhaluan kanan dan sebagai hasilnya mereka menerbitkan buku bertajuk Overview of the Greater East Asia War pada tahun 1995. Buku ini berpendapat bahawa Perang Asia Pasifik bukan perang agresif, tetapi perang untuk pertahanan diri dan untuk membebaskan Asia dari kuasa Barat. ${ }^{68}$ Manakala dalam isu hamba seks pula ketika menjadi Ketua Setiausaha Kabinet, Abe telah mengkritik kandungan dokumentari NHK (syarikat penyiaran milik negara) tentang hamba seks sebelum disiarkan. Beliau meminta supaya ketua Biro Penyiaran membuat dokumentari yang adil dan objektif atau mengundurkan diri. Hasilnya dari kritikan tersebut perubahan ketara telah dibuat dalam dokumentari yang ditayangkan pada 30 Januari 2001. Salah satu perubahan ialah pemotongan bahagian Tribunal Jenayah Perang Antarabangsa Wanita yang diadakan di Tokyo pada Disember 2000 yang menganggap sistem perhambaan seks oleh tentera Jepun sebagai

\footnotetext{
65 Ibid.

66 Yuji Sasagase, Keita Hayashi, Kei Sato, “Japan’s Largest Rightwing Organization: An Introduction to Nippon Kaigi."

${ }^{67}$ Tawara Yoshifumi. "What is the Aim of Nippon Kaigi," hlm. 2.

${ }^{68}$ Narusawa Muneo, “Abe Shinzo: Japan’s New Prime Minister a Far-Right Denier of History,” The Asia-Pacific Journal. Vol. 11, No. 1, 2013, hlm. 2.
} 
jenayah terhadap kemanusiaan dan Jepun serta Maharaja Hirohito perlu bertanggungjawab. ${ }^{69}$ Manakala dalam isu Kenyataan Kono pula menyaksikan pada 14 Jun 2004 Abe mengumumkan dalam simposium yang dianjurkan oleh Kumpulan Ahli Diet untuk Pertimbangan Pendidikan Masa Depan dan Sejarah Jepun (Group of Diet Members for Consideration of Japan's Future and History Education) bahawa tidak ada fakta sejarah tentang perhambaan seks dan meminta kerajaan Jepun supaya mengeluarkan kenyataan baharu untuk menggantikan Kenyataan Kono. ${ }^{70}$

Berikutan beberapa fakta yang dianggap oleh Abe sebagai menyeleweng tentang aktiviti perang Jepun maka beliau merupakan personaliti yang sentiasa berada di barisan hadapan dalam membetulkannya terutama dalam buku teks sekolah. Beliau menekankan bahawa bukan sahaja pegawai kementerian pendidikan yang bertanggungjawab untuk memeriksa buku teks, tetapi juga penerbit dan penulis perlu menghapuskan rujukan terhadap jenayah tersebut. ${ }^{71}$ Oleh kerana buku teks sekolah mengandungi maklumat tidak benar, maka Abe menyokong rombakan semula buku teks dibuat.

Berikutan keselarian dalam perjuangan Nippon Kaigi dengan Abe, maka adalah tidak mustahil Abe menyokong perjuangan pertubuhan tersebut dengan menyertainya sebagai penasihat. Sokongan Abe kepada perjuangan Nippon Kaigi diperkuatkan lagi dari segi pembentukan kabinet beliau. Pada 26 Disember 2012, Abe mengumumkan 13 dari 19 termasuk beliau dalam kabinet baharunya adalah mereka yang secara konsisten menyokong perjuangan Nippon Kaigi. Bilangan yang ramai dalam kabinet juga menunjukkan sifat berhaluan kanan pentadbiran Abe. Antara ahli kabinet tersebut adalah Sanae Takaichi yang terkenal dengan desakan supaya kerajaan mengeluarkan penyataan baharu untuk menggantikan Kenyataan Kono pada tahun 2015 apabila Jepun meraikan ulang tahun ke-70 penyerahan kalah dalam Perang Dunia Kedua. Eriko Yamatani pula terkenal dengan kenyataan tidak sensitif terhadap isu tuntutan bertindih dan perhambaan seks tentera. Hakubun Shimomura yang terkenal dengan pandangan yang mahu kandungan sejarah dalam pendidikan dirombak semula. Manakala Wataru Takeshita membuat kenyataan kontroversi seperti pada Jun 2014, “Until we get back Takeshima, we can't say that the postwar system is over. When Korea holds fashion shows on Takeshima and lands on it via helicopter, it feels like my body is being torn apart."

Pada masa sekarang kekuatan Nippon Kaigi semakin berkembang seiring dengan perkembangan sokongan yang diterima dari ahli politik dan rakyat serta di peringkat kerajaan tempatan. Tambahan lagi dengan persekitaran hubungan politik yang tidak stabil dengan negaranegara jirannya menyebabkan timbul keperluan menyokong pertubuhan berhaluan kanan yang boleh mengimbangi ancaman negara-negara tersebut.

Walau bagaimanapun terdapat kritikan ke atas Nippon Kaigi yang menunjukkan kewujudan organisasi tersebut juga tidak diterima oleh sesetengah pihak di Jepun. Contohnya pakar perlembagaan dan bekas ahli Nippon Kaigi, Setsu Kobayashi mengatakan bahawa Nippon Kaigi tidak dapat menerima realiti kekalahan dalam Perang Dunia Kedua. ${ }^{72}$ Kobayashi juga mengatakan bahawa pemikiran Nippon Kaigi adalah membahayakan kerana menganggap bahawa Jepun adalah pemimpin Asia seperti sebelum perang dan mahu mengulanginya pada masa sekarang. Beliau bimbang pemikiran seperti ini akan membawa kembali Jepun kepada pentadbiran kuku besi, ketiadaan kebebasan dan demokrasi seperti zaman perang. ${ }^{73}$

\footnotetext{
69 Ibid.

${ }^{70}$ Ibid. hlm. 4.

71 Ibid. hlm. 2.

72 David McNeill, "Nippon Kaigi and the Radical Conservative Project to Take Back Japan,” hlm. 3.

73 Ibid.
} 


\section{KESIMPULAN}

Dari penjelasan di atas, jelas pertubuhan ini memperlihatkan keinginan yang kuat untuk mengukuhkan nasionalisme melalui pembetulan apa yang dilihat sebagai satu kesongsangan Jepun. Bagaimana matlamat ini dapat direalisasikan? Jawapannya adalah dari segi pergerakan terancang pertubuhan tersebut yang berjaya mendapat sokongan bukan sahaja dari rakyat tetapi juga dari kalangan pemimpin elit parti politik, kerajaan dan swasta yang turut menganggotai pertubuhan tersebut. Mereka menjalankan lobi kepada Perdana Menteri dan menteri kabinet serta ahli politik dalam parlimen. Lebih mudah lagi perjuangan mereka selari dengan dasar keutamaan Shinzo Abe iaitu "ke arah negara indah" (utsukushii kuni e) seperti perlembagaan, pendidikan dan pertahanan.

Pergerakan pertubuhan ini juga tidak melalui keganasan dan kekerasan seperti yang dilakukan oleh pertubuhan haluan kanan di negara-negara lain tetapi melalui aktiviti propaganda politik. Untuk menyebarkan ideologi dalam kalangan orang ramai, ia meletakkan keutamaan tertinggi dalam perhimpunan kebangsaan besar, mengumpul tandatangan dan meluluskan resolusi dewan tempatan di seluruh negara. Dalam erti kata itu, boleh dikatakan bahawa Nippon Kaigi merupakan pendekatan baharu untuk pergerakan sivil berhaluan kanan.

Keseluruhannya, dilihat dari sudut pandangan masyarakat luar Jepun yang pergerakan dijalankan bagi Nippon Kaigi adalah keterlaluan kerana banyak memesongkan fakta sejarah yang telah sekian lama ditanam dalam pemikiran mereka. Walau bagaimanapun dilihat dari sudut pandangan Nippon Kaigi, mereka berhak untuk menanam semangat nasionalisme dalam masyarakat Jepun kerana pemikiran cintakan negara adalah sangat diperlukan bagi mempertahankan negara dari diserang dari segi fizikal dan mental. Begitu juga dari aspek membangunkan negara yang memerlukan semangat nasionalisme yang tinggi dari kalangan rakyat. Justifikasi bagi menanam semangat ini adalah dengan mendedahkan fakta sebenar versi Jepun seperti penolakan sejarah keganasan Jepun dan digantikan dengan sumbangan besar Jepun kepada negara luar.

\section{RUJUKAN}

"3 Japan Cabinet ministers Visit Controversial Yasukuni Shrine a Day after PM Abe's offering," The Straits Times, 18 October 2014.

Asmadi Hassan, 'Nippon Izokukai and the Controversial Visit of the Japanese Prime Minister to the Yasukuni Shrine,' in Muhammad Danial Azman \& Geetha Govindasamy, Insight to East Asia: Bridging the Past and Present, Kuala Lumpur: University of Malaya Press, 2018.

Asmadi Hassan, Rohayati Paidi, "Gerakan Penentangan Pemindahan Mcas Futenma ke Henoko di Okinawa, Jepun oleh All Okinawa Council." Jebat: Malaysian Journal of History, Politics \& Strategic Studies, Vol. 47. No.2, 2020.

Carney, Matthew, "Nippon Kaigi: the Ultra-Nationalistic Group Trying to Restore the Might of the Japanese Empire," ABC News, 2 December 2015.

"Conservative Group behind Pro-Constitutional Amendment Petition Collecting," Mainichi Japan, 4 May 2016. 
“Cross-party Group of around 70 Lawmakers Visits Japan's War-Linked Yasukuni Shrine," The Japan Times, 23 April 2019.

Field, Norma, Tomomi Yamaguchi. "Comfort Woman' Revisionism Comes to the U.S.: Symposium on the Revisionist Film Screening Event at Central Washington University," The Asia-Pacific Journal, Vol. 13, No. 1, 2015.

"Japan PM Abe refrains from visiting Yasukuni Shrine on WWII Anniversary," Nikkei Asian Review, 15 August 2018.

“Japan's 'Comfort Women'," Analysis, 14 January 2018.

“Japanese Lawmakers Visit War-Linked Yasukuni Shrine. Kyodo News, 23 April 2019.

"Japanese Politicians Upset South Korea with Visit to Yasukuni Shrine," The Guardian, 18 Oktober 2016.

Kato, Norihiro, “Tea Party Politics in Japan: Japan's Rising Nationalism," The International New York Times, 13 September 2014.

Kingston, Jeff, “Japan’s Constitutional Rebirth or Reincarnation,” The Japan Times, 13 May 2017.

Kingston, Jeff, “The Japan Lobby and Public Diplomacy,” The Asia-Pacific Journal, Vol. 14, No. 2, 2016.

Kim, Hyun-ki, “Nationalist 'Japan Conference' Building its Clout,” Korea JoonAng Daily. 3 May 2013.

McNeill, David, "Nippon Kaigi and the Radical Conservative Project to Take Back Japan, ” The Asia-Pacific Journal, Vol. 13, No. 4, 2015.

Mizohata, Sachie, “Nippon Kaigi: Empire, Contradiction, and Japan's Future," The Asia-Pacific Journal, Vol. 14, No. 4, 2016.

Mullins, Mark R., "Neonationalism, Religion, and Patriotic Education in Post Disaster Japan,” The Asia-Pacific Journal, Vol. 14, No. 5, 2016.

Mullins, Mark R., "The Neo-Nationalist Response to the Aum Crisis A Return of Civil Religion and Coercion in the Public Sphere?” Japanese Journal of Religious Studies, Vol. 39, No. 1, 2012.

Muneo, Narusawa, “Abe Shinzo: Japan's New Prime Minister a Far-Right Denier of History,” The Asia-Pacific Journal. Vol. 11, No. 1, 2013.

Nakano, Koichi, "Contemporary Political Dynamics of Japanese Nationalism," The Asia-Pacific Journal, Vol. 14. No. 6, 2016. 
"No Cabinet Members Visited Yasukuni Shrine on War Anniversary," Mainichi Japan, 16 August 2017.

Penney, Matthew, "The Abe Cabinet - An Ideological Breakdown," The Asia-Pacific Journal. Vol. 10, No. 137, 2012.

Postel-Vinay, Karoline, Sciences Po, "The Global Rightist Turn, Nationalism and Japan," The Asia-Pacific Journal. Vol. 15, No. 1, 2017.

"Politics in Japan: Right Side Up," The Economist, 4 June 2015.

“Pro-Yasukuni Lineup Features Aso Cabinet," Japan Press Weekly, 25 September 2008.

“Pro-Yasukuni Parliementary Groups Backing Up Abe Cabinet,” Akahata, 22 May 2007.

Rogin, Josh, "Japanese Comfort-women Denires Force White House Response." The Cable, 6 June 2012Saaler, Sven, "Nationalism and History in Contemporary Japan." The Asia-Pacific Journal, Vol. 14, No. 7, 2016.

Sakurai, Yoshiko, “Can LDP Manage to Consolidate Proposals for Revision of Article 9 of Japan's Pacifist Constitution?,” The Weekly Shincho, No. 794, 15 March 2018.

Sakurai, Yoshiko "Hostile Anti-Abe Media Hampering Constitutional Revision" The Weekly Shincho, No. 797, 5 April 2018.

Shibuichi , Daiki, "The Yasukuni Shrine Dispute and the Politics of Identity in Japan: Why All the Fuss?” Asian Survey, Vol. 45, No. 2, 2005.

Sim, Walter, "Most Influential Right-wing Pressure Group in Japan.” The Straits Times, 2 May 2017.

Sonoda, Koji, “Japan Conference's Quest for Constitutional Revision,” The Japan Times, 7 June 2016.

Syed Ahmad Hussein, Pengantar Sains Politik, Kuala Lumpur: Dewan Bahasa dan Pustaka, 2006. Tawara Yoshifumi, "What is the Aim of Nippon Kaigi, the Ultra-Right Organization that Supports Japan's Abe Administration?” The Asia-Pacific Journal, Vol. 15, No. 1, 2017.

Taguchi, Fukuji, "Pressure Groups in Japanese Politics," The Developing Economies, Vol. 6, No. 4, 1968.

Weiss Andrew, "Towards a Beautiful Japan: Right-Wing Religious Nationalism in Japan's LDP", Eli Scholar, 2018

Yamaguch, Tomomi, "The "Japan Is Great!" Boom, Historical Revisionism, and the Government," The Asia-Pacific Journal, Vol. 15, No. 3, 2017. 
Yoshida, Reiji,, “Abe's Nationalism Reflected in Conservative Political Movement, but Polls Show Voter Dissent," The Japan Times, 14 Ogos 2015.

Yoshida, Reiji, “Thousands Rally in Nippon Budokan Hall for Constitutional Change,” The Japan Times, 10 November 2015.

Yuji Sasagase, Keita Hayashi, Sato Kei, “Japan's Largest Rightwing Organization: An Introduction to Nippon Kaigi,” The Asia-Pacific Journal, Vol. 13, No. 5, 2015. 